\title{
Yield and crown structure characteristics in a red oak (Quercus rubra L.) stand: Case study
}

\author{
Fruzsina Szabó ${ }^{1}$ - Tamás Ábri ${ }^{1,2 *}$ - Károly Rédei ${ }^{1}$ \\ ${ }^{1}$ Faculty of Agricultural and Food Sciences and Environmental Management, University of Debrecen, Debrecen, Hungary \\ ${ }^{2}$ Forest Research Institute, Department of Plantation Forestry, University of Sopron, Püspökladány, Hungary \\ *Correspondence: abri.tamas@uni-sopron.hu
}

\begin{abstract}
SUMMARY
The paper provides the results of a detailed analysis of timber volume and several important crown variables of red oak (Quercus rubra L.) based on an experimental plot in eastern Hungary. At the age 32 years the crop trees belonged to different height classes. If the volume of the mean tree from height class I was considered as 100\%, the volume of the mean tree of class II was 59\%, and the mean tree of class III was only 36\%. It appeared that there was a significant correlation between crown indices and yield. For this reason, diameter at breast height showed a positive linear correlation with crown diameter $\left(R^{2}=0.6211\right)$. Additionally, there was also positive linear relationship between crown diameter and volume $\left(R^{2}=0.6908\right)$. The variation of crown indices is height even within the same stand and indicates the importance of following a selective thinning operation method.
\end{abstract}

Keywords: volume production, crown indices, non-native tree species

\section{INTRODUCTION}

The northern red oak (Quercus rubra L.) is an intermediate shade tolerant tree species, native to North America (Sander, 1990). It was introduced to Europe in 1691 (Réh, 1989; Hejný and Slavík, 1990) and currently covers over 350000 ha (Nicolescu et al., 2018). It is most widespread in Germany (44 000 ha), France (43 000 ha) and Spain (20 000 ha) (Hasenauer, 2016). In arid areas red oak was used to replace domestic European oaks that suffered from dieback (Burkovský, 1985; Gubka and Špišák, 2010). Northern red oak appears not only more resistant to diseases but also demonstrates better early growth and better adaptation to dry sites (Miltner and Kupka, 2016).

Northern red oak provides ecosystem services like soil protection (Kupka and Dimitrovský, 2011; Nagel, 2015), carbon sequestration and habitat for wild animals (Goßner, 2004; Goßner and Simon, 2005; Nagel, 2015). The species is very decorative with large and crimson-colored crown; it has a good resistance to air pollution (Miltner and Kupka, 2016) and high landscape value, the tree is used in parks, gardens and as street tree (Brus, 2011).

Red oak produces a well closings and favourably differentiated stand structures due to the great genetic diversity of individual trees (Szappanos and Nagy, 1978; Rédei et al., 2010). Northern red oak utilizes the leaks of thinnings well. The number of crop trees released within red oak stands varies depending on site quality, species composition, stand age, and management objectives. Total volume production per unit area between thinned and unthinned stands does not differ greatly (Rédei et al., 2018). The species has a high wood production (Kupka et al., 2018). This coarse-grained wood is hard, strong, stiff, with good workability, impregnation and splitting potential (Lorent and de Wouters, 2001). It is a versatile timber used for lumber, furniture, veneer (less decorative than the one of native oaks - Mazet, 1988), in construction, for the interior finish of houses, railroad ties, as mine wood, firewood, etc. (Réh and Réh, 1997; Vansteenkiste et al., 2005).

The red oak can be considered the third most important exotic stand-forming tree species in Hungary. It appeared in Hungary in the middle of the 19th century and has adapted in large measure to site conditions in the country. Due to its advantageous silvicultural and yield characteristics, it recently covers approximately 15000 ha. The most important growing areas are in Baranya, Vas, Zala, Somogy and SzabolcsSzatmár-Bereg counties (Járó, 1957; Rédei et al., 2007).

Yield trends and the absolute value of yield at a given age are determined by complex interactions of environmental and site factors (Rédei and Meilby, 2000). Many researchers have focused on the structure of stands and individual tree, but few prior studies have addressed the issue of the analysis of correlations between crown parameters and volume production. They are frequently required for growth modelling with tree growth estimated from crown and other tree characteristics. The methods described (and stand structure modelling possibilities as well) can help the practical managing of stands with an optimal structure on the basis of known or previously determined parameters.

\section{MATERIALS AND METHODS}

The experimental plot $\left(1000 \mathrm{~m}^{2}\right)$ was selected in the Trans-Tisza region (subcompartment: Debrecen-Józsa $4 \mathrm{G})$ in a 32 years old red oak stand (Figure 1). According to the Hungarian site classification (Járó, 1972), the main ecological characteristics of the study area are as follows:

(i) Turkey oak-sessile oak forest climate (humidity between $48-53 \%$ in July at $2 \mathrm{pm}$; annual precipitation exceeds $600 \mathrm{~mm}$ );

(ii) hydrology: periodic water effect; 
(iii) genetic soil type: humic sandy soil.

The most important red oak growing regions in Hungary are located in southern Transdanubia (hill ridges of Somogy County) and north-eastern Hungary (Nyírség region). The species requires loose to slightly dense soils, well aerated without too much moisture, with physiologically favorable depths over $60 \mathrm{~cm}$, and humus content from moderately high to very high.

The sample plot included 52 trees. For each tree diameter (at breast height), height, basal area, as well as its spatial distribution were measured. Three height classes were recognized in the sample plot (Kraft, 1884):

(i) Dominant trees, with crowns extending above the general level of the crown layer and receiving full light from above and partly from the side; larger than the average trees in the stand with well-developed crowns;

(ii) Co-dominant trees, with crowns forming the general level of the crown layer and receiving full light from above, but comparatively little light from the sides; usually with medium-sized crowns and more or less crowded on the sides;

(iii) Intermediate trees, shorter than those in the two preceding classes, but with crowns either below or extending into the canopy of codominant and dominant trees. As a result, they usually have small crowns and are considerably crowded on the sides.

\section{Figure 1. Location of the study site (subcompartment: Debrecen-Józsa 4G) within the Hajdú-Bihar county in eastern Hungary}

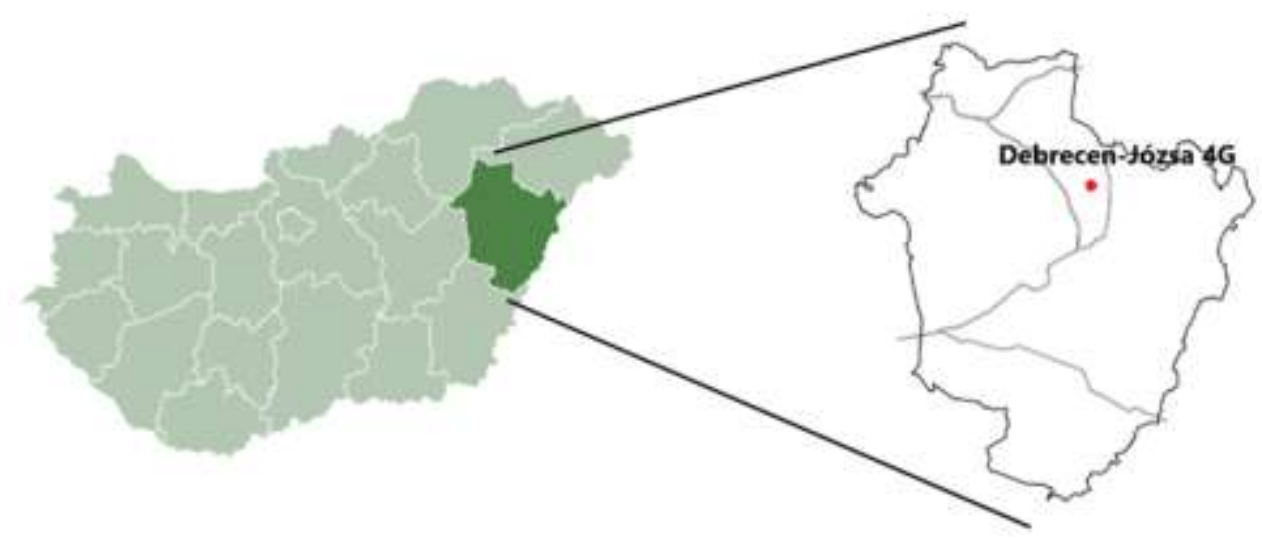

Tree volume $\left(\mathrm{v}, \mathrm{m}^{3}\right)$ was calculated based on Eq.1 (Sopp and Kolozs, 2013):

$$
\mathrm{v}=\left(\mathrm{p}_{1}+\mathrm{p}_{2} \mathrm{dh}+\mathrm{p}_{3} \mathrm{~d}+\mathrm{p}_{4} \mathrm{~h}\right)(\mathrm{h} /(\mathrm{h}-1,3))^{\mathrm{k}} \mathrm{dbh} \mathrm{h}^{2} / 10^{8}
$$

where:

$$
\begin{aligned}
& \mathrm{p}_{1}=5.6391 \mathrm{E}-01, \\
& \mathrm{p}_{2}=2.6553 \mathrm{E}-05, \\
& \mathrm{p}_{3}=-1.6023 \mathrm{E}-03, \\
& \mathrm{p}_{4}=-1.5616 \mathrm{E}-03, \\
& \mathrm{k}=1,
\end{aligned}
$$$$
\mathrm{v} \text { - mean tree volume }\left(\mathrm{m}^{3}\right) \text {, }
$$$$
\mathrm{dbh} \text { - diameter at breast height }(\mathrm{cm}) \text { of each tree, }
$$$$
\mathrm{h} \text { - tree height }(\mathrm{m}) \text {. }
$$

Based on the estimated individual tree volumes, stand volume $\left(\mathrm{V}, \mathrm{m}^{3} \mathrm{ha}^{-1}\right)$ (Eq. 2) and mean tree volume $\left(\bar{v}, \mathrm{~m}^{3}\right)($ Eq. 3$)$ were also derived:

$$
\begin{aligned}
& \mathrm{V}=\left(\mathrm{v}_{1}+\ldots \mathrm{v}_{52}\right) * 10 \\
& \bar{v}=V / N
\end{aligned}
$$

where:

$\mathrm{N}$ - number of stems per hectare.
The most important structural factors and variables in connection with the crown are the followings (Laar and Akca, 2007):

(i) crown diameter - $\mathrm{CD}(\mathrm{m})$;

(ii) crown projection area-CPA $\left(\mathrm{m}^{2}\right)($ Eq. 4$)$ :

$$
\mathrm{CPA}=\left(C D^{\wedge} 2 * \pi\right) / 4
$$

(iii) crown spread ratio (Eq. 5): crown spread ratio $=C D / H * 100$,

where $\mathrm{H}=$ mean height of the stand

(iv) linear crown index (Eq. 6):

linear crown index $=C D / D B H$,

where $\mathrm{DBH}=$ mean diameter (at breast height) of the stand

\section{RESULTS AND DISCUSSION}

The most important stand structure parameters by height classes are shown in Table 1. Determined that height class is the most important factor in tree diameter growth.

The data of the table shows clear significant differences between the mean trees of different height 
classes. There are differences in height and diameter at breast height, similarly there are differences in total volume and mean tree volume. If the volume of the mean tree in height class I is taken as $100 \%$, then class II is only $59 \%$ and class III is not more than $36 \%$.

The crown spread ratio is decreasing from one height class to another. The linear crown index is higher in the lower height classes (Table 2).

In order to make the analyses as complete as possible, several linear regressions were fitted: between
DBH and crown diameter; crown diameter and volume; crown length and volume and tree height.

There is a positive linear relationship between diameter at breast height and crown diameter. The correlation $\left(\mathrm{R}^{2}=0.6211\right)$ suggest a high accuracy for predicting crown diameters from diameter at breast height (Figure 2). Crown diameter also show positive linear correlations with volume $\left(\mathrm{R}^{2}=0.6908\right)$ (Figure 3).

Table 1. Stand level attributes grouped by height classes (Forest Subcompartment: Debrecen-Józsa 4G)

\begin{tabular}{|c|c|c|c|c|c|c|c|c|}
\hline \multirow[t]{2}{*}{ Height class } & \multicolumn{2}{|c|}{ No. of stems per hectare } & \multirow{2}{*}{$\begin{array}{c}\text { Mean height } \\
(\mathbf{m})\end{array}$} & \multirow{2}{*}{$\begin{array}{c}\text { Mean DBH } \\
(\mathrm{cm})\end{array}$} & \multirow{2}{*}{$\begin{array}{c}\text { Basal area } \\
\left(\mathbf{m}^{2} \mathbf{h a}^{-1}\right)\end{array}$} & \multicolumn{2}{|c|}{ Volume per hectare } & \multirow{2}{*}{$\begin{array}{c}\text { Volume of mean tree } \\
\left(\mathbf{m}^{\mathbf{3}}\right)\end{array}$} \\
\hline & $(-)$ & $(\%)$ & & & & $\left(\mathbf{m}^{3}\right)$ & $\%$ & \\
\hline I & 90 & 17 & 22.3 & 27.8 & 5.46 & 66.62 & 30 & 0.740 \\
\hline II & 230 & 44 & 20.2 & 22.0 & 8.74 & 100.48 & 46 & 0.437 \\
\hline III & 200 & 38 & 19.3 & 17.7 & 4.91 & 52.94 & 24 & 0.265 \\
\hline Total or average & 520 & 100 & 20.6 & 22.5 & 19.12 & 220.05 & 100 & 0.481 \\
\hline
\end{tabular}

Table 2. Crown parameters by height classes (Forest Subcompartment: Debrecen-Józsa 4G)

\begin{tabular}{ccccc}
\hline Height class & $\begin{array}{c}\text { Diameter } \\
(\mathbf{m})\end{array}$ & $\begin{array}{c}\text { Spread ratio } \\
(\mathbf{\%})\end{array}$ & Linear index & $\begin{array}{c}\text { Projection area } \\
\left(\mathbf{m}^{\mathbf{2}}\right)\end{array}$ \\
\hline I & 7.4 & 33.2 & 26.62 & 43.01 \\
II & 5.8 & 28.7 & 26.36 & 26.42 \\
III & 4.2 & 21.7 & 23.76 & $\mathbf{2 5 . 5 8}$ \\
\hline Average & $\mathbf{5 . 8}$ & $\mathbf{2 7 . 9}$ & $\mathbf{2 7 . 7 6}$ \\
\hline
\end{tabular}

Figure 2. Correlation between crown diameter (CD) and diameter at breast height (dbh)

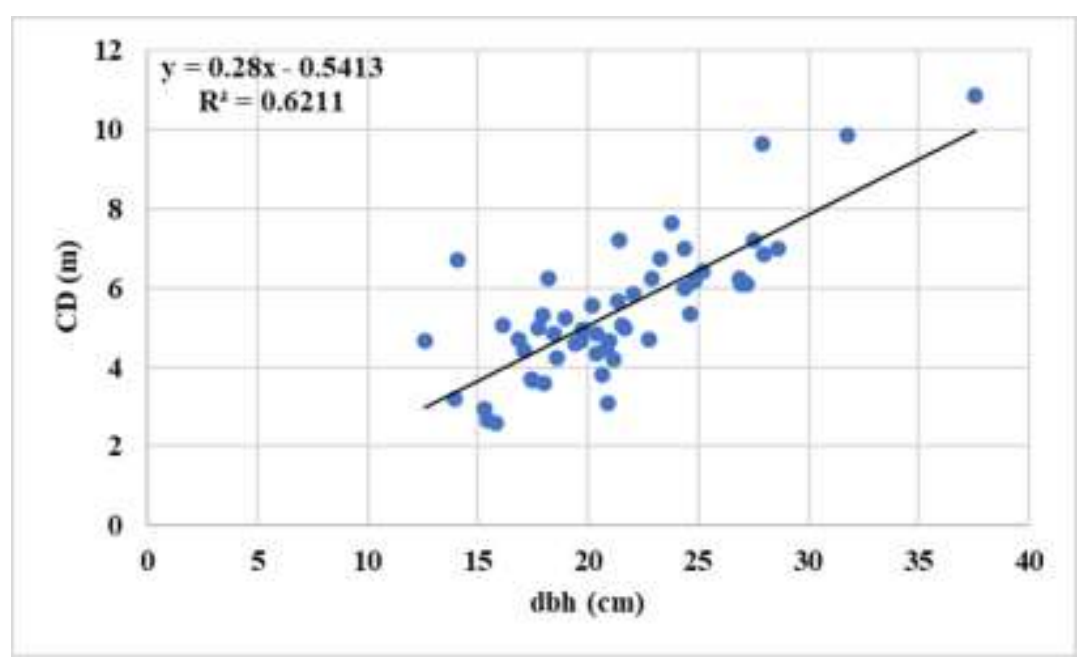

This publication is a case study. The tree crops inside the experimental plot give us the analysis of the stand structure. A part of our conclusions could have a general view in the reference of the red oak. The results show that there is a relationship between the structural setup and the yield of individual trees and the overall yield from stands. The complex analysis of these relationships can help us better understand the drivers of red oak productivity.

The study of trees by height classes allows the accurate separation of production levels as well as an exact determination of the structural parameters for trees with the highest productivity rates. 


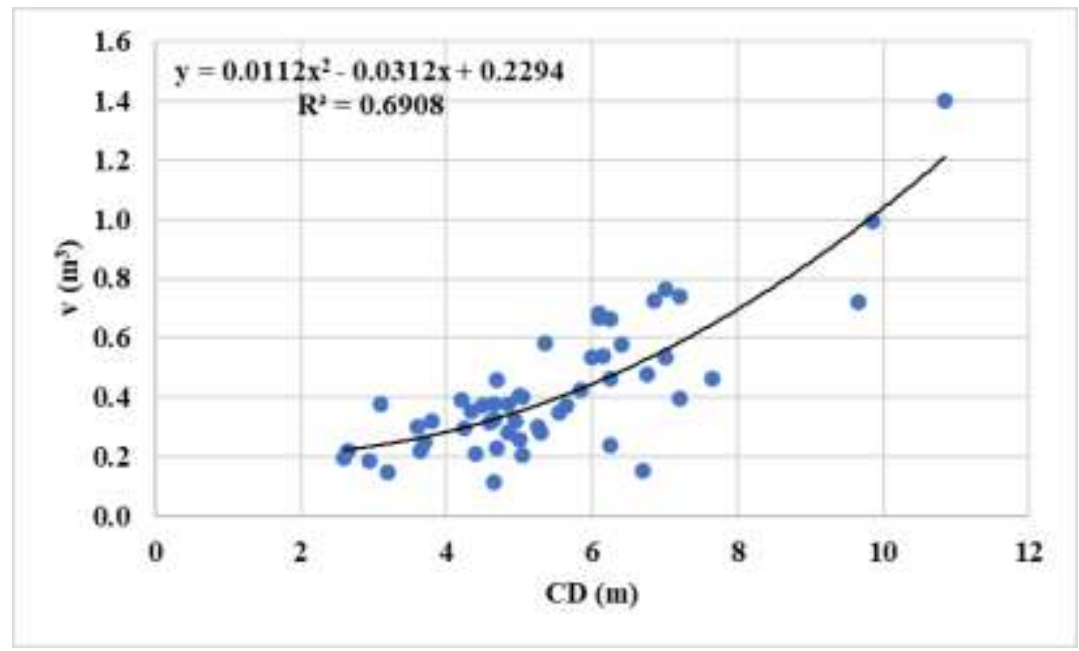

From the data presented here, it appears that there is a significant correlation between crown indices and yield. There also appears to be a strong correlation between diameter at breast height (which affects the volume) and crown diameter:

Assuming that the targeted DBH is $22.5 \mathrm{~cm}$, the suggested $\mathrm{N}$ is as follows (Eq. 7):

$$
\mathrm{N}=10 \text { 000/CPA }
$$

In our case, $\mathrm{N}$ is as follows (Eq. 8):

$$
\mathrm{N}=10000 / 26.42=378
$$

\section{CONCLUSIONS}

According to our investigations it is obvious that height class is the most important factor in tree diameter growth. Height class is the result of the competitive pressure that takes places as trees increase in size. Red oak trees rarely increase their height class over time unless a timber harvest/thinning operation or other significant stand disturbance remove larger competitors and release growing space. Based on our repeated measurements in other red oak stands if a tree achieves a dominant or codominant height class, it must maintain that canopy position by growing faster than its competitors or it will eventually subside under the competitive pressure of its neighbors. The reserved results have built upon the main stand component species referring to the red oak as a comparison on silvicultural treatment models. We can use these models effectively in the phase of planning, implementation and verification. The task of thinnings is to manipulate height classes and growing space to favour trees that satisfy management objectives. To fulfil this requirement tending operation models can be available in the Hungarian forest management practice.

\section{REFERENCES}

Brus, R. (2011): Dendrology for Foresters. Univerza v Ljubljani, Biotehniška fakulteta pp., 408.

Burkovský, J. (1985): Viac pozornosti hromadnému hynutiu dubov v chraněných územiach. Pamiatky prirody, 1: 26-27. (in Czech)

Goßner, M. - Simon, U. (2005): Effect of introduced Quercus rubra L. (Red Oak) on a specialised phytophagus guild in Germany a case study of seed infesting insects (Coleoptera, Lepidoptera). In Biological Invasions - From Ecology to Control. W. Nentwig, S. Bacher, M.J.W. Cock, H. Dietz, A. Gigon and R. Wittenberg (Eds.). In Neobiota, 6, pp. 89-109.

Goßner, M. (2004): Diversity and structure of arthropods on alien and native tree species. Investigation of selected arthropod groups for a faunistic-ecological assessment of Douglas-fir (Pseudotsuga menziesii (Mirb.) Franco) and northern red oak (Quercus rubra L.) plantations. Ph.D Thesis, Technical University Munich, pp. 241.

Gubka, K.-Špišák, J. (2010): Prirodzená obnova duba červeného ( $Q$. rubra L.) na výskumných plochách Semerovce (LS Šahy). In
Knott R., Peňáz J., Vaněk P. (eds). Pěstování lesů V nižších vegetačních stupních. Brno, Mendel University in Brno: 30-34. (in Czech)

Hasenauer, H. (ed.) (2016): Non-Native Tree Species for European Forests: Experiences, Risks and Opportuni-ties. Country reports. COST Action FP1403. Vienna

Hejný, S.-Slavík, B. (1990): Květena České republiky. Svazek 2. Prague, Academia: 544. (in Czech)

Járó, Z. (1957): A vöröstölgy növekedési viszonyai. Az Erdő 6 (2): 63-67. (in Hungarian)

Járó, Z. (1972): A termőhely fogalma. In: Danszky I. (ed.): Erdőművelés I. Mezőgazdasági Kiadó, Budapest, 47-87. (in Hungarian)

Kraft, G. (1884): Beiträge zur Lehre von den Durchforstungen, Schlagstellungen und Lichtungshieben. Hannover, Klindworth's Verlag: 154. (in German)

Kupka, I.-Baláš, M.-Miltner, S. (2018): Quantitative and qualitative evaluation of Northern red oak (Quercus rubra L.) in arid areas 
of North-Western Bohemia. Journal of Forest Science, 64:5358.

Kupka, I.-Dimitrovsý, K. (2011): Test results of selected tree species for forestry reclamations in the Sokolov region: a review. Zprávy lesnického výzkumu, 52-56.

Laar, A.-Akca, A. (2007): Forest Mensuration, 2nd ed.; Springer Netherlands, Berlin, p. 385

Lorent, V.-de Wouters, Ph. (2001): Northern red oak wood. Essence. Fiche technique no. 3. Silva Belgica 5, I-II.

Mazet, J.F. (1988): Colour and quality of oak veneers and study of their photochemical behaviour. Ph.D. Thesis, University of Nancy 1, Nancy, pp. 136

Miltner, S.-Kupka, I. (2016): Silvicultural potential of northern red oak and its regeneration- Review. Journal of Forest Science, 62:145-152.

Nagel, R.V. (2015): Northern red oak. In Potentials and risks of introduced tree species. Vor T., Spellmann H., Bolte A. and Ammer C. (eds). Göttinger Forstwissenschaften 7, pp. 219-267.

Nicolescu, N.V.-Vor, T.-Mason, W.L.-Bastien, J.C.-Brus, R.Henin, J.M.-Kupka, I.-Lavnyy, V.-La Porta, N.-Mohren, F.Krasimira, P.-Rédei, K.-Štefančik, I.-Wąsik, R.-Perić, S.Hernea, C. (2018): Ecology and management of northern red oak (Quercus rubra L. syn. Q. borealis F. Michx.) in Europe: a review. Forestry. https://doi.org/10.1093/forestry/cpy032.

Rédei, K.-Csiha, I.-Keserü, Zs.-Rásó, J.-Győri, J. (2010): Management of red oak (Quercus rubra L.) stands in the Nyírség forest region (Eastern Hungary). Hungarian Agricultural Research 19: 13-17.

Rédei, K.-Csiha, I.-Rásó, J.-Kovács, Cs.-Bakti, B.-Kiss, T.Keserü, Zs. (2018): Tending cutting and target diameter tables for Northern red oak (Quercus rubra L.) stands in Hungary. Acta
Silvatica et Lignaria Hungarica 14 (2): 107-112. DOI:10.2478/aslh-2018-0007

Rédei, K.-Meilby, H. (2000): Effect of thinning on the diameter increment in black locust stand (Robinia pseuodacacia L.). Silva Gandavensis, 65: 115-127.

Rédei, K.-Veperdi, I.-Csiha, I. (2007): Yield of red oak stand in the Nyírség forest region (Eastern Hungary). Silva Lusitana 15 (1): 79-87.

Réh, J.-Réh, R. (1997): Red oak (Quercus rubra L.), development, structure and growth processes in consequence of thinning and its utilization possibility in wood-processing industry. Technická univerzita, Zvolen, pp. 71.

Réh, J. (1989): Vývoj, štruktúra a rastové procesy žrd'ovín duba červeného (Quercus rubra L.) vplyvom prebierok. Správa pre zaverečnú oponentúru čiastkovej úlohy. Zvolen, LF VŠLD vo Zvolene: 212. (in Czech)

Sander, I.L. (1990): Northern red oak (Quercus rubra L.). In: Silvics of North America. Vol. 2. Hardwoods. Burns R.M. and Honkala B.H. (eds). (Coord.). USDA, Forest Service, Agriculture Handbook no. 654, pp. 727-733.

Sopp, L.-Kolozs, L. (eds) (2013): Wood Volume Tables. 4th Ed. Budapest, National Food Chain Safety Office, Forest Management: 279. (in Hungarian)

Szappanos, A.-Nagy, S. (1978): Faállomány-szerkezeti vizsgálatok tisztítási korú vöröstölgyesekben. Erdészeti és Faipari Egyetem Tudományos Közleményei 23-37. Sopron. (in Hungarian)

Vansteenkiste, D.-de Boever, L.-van Acker, J. (2005): Alternative processing solutions for red oak (Quercus rubra) from converted forests in Flanders, Belgium. Lignovisionen 9, 13-26. 